\title{
HUMAN RESOURCE DEVELOPMENT IN THE ERA OF TECHNOLOGY; TECHNOLOGY'S IMPLEMENTATION FOR INNOVATIVE HUMAN RESOURCE DEVELOPMENT ${ }^{1}$
}

\author{
Ince Ahmad Zarqana \& Sukarni Sb \\ aPresident University \& bUniversitas Pelita Bangsa
}

\begin{abstract}
Rapid changes in technology have affected businesses in an uncountable way, strength of a company can be measured based on the level of technology that implemented for the sake of efficiency, it posseses that the "technovation" (technology and innovation) is one of the key for improvement of human resource. Surely, it is a single important factor for a human resource management as an organization should be able to identify an improvement of its human resources. Thus, the primary purpose of the present paper is to analyse the current effects of technology on HR processes, consider the existing literature on the topic, and discuss the advantages and efficiency. In this scenario, there is a need to clearly identify a technology for an efficient management of human resources which is able to improve skills of the employees. A number of key areas of the impacts of technology on human resource development that are discussed in order to gain an innovative human resource development.
\end{abstract}

Keyword : Human Resource, Development, Technology, Improvement

\footnotetext{
1 this paper has been presented at ICEBA 2017: 1st International Conference on Economics, Business and Accounting 2017, conducted by Pelita Bangsa University and LPP Cendekia, at Cikarang, Bekasi, West Java, Indonesia, May 19th 2017
} 


\section{Ince Ahmad Zarqan}

\section{Sukarni S}

\section{INTRODUCTION}

Nowadays, most of organizations are facing a number of challenges: intensified globalization, improvement of market competition, changing workforce demographics, rapidly changing technology and e-business, just to name a few. Of these, technology has perhaps made the most profound influence on the activities of organizations. Based on a research by Carroll and Wager (2010) that summarize, "technology has further revolutionized the ways in which many companies do business, forcing a paradigm shift for management that has resulted in new and innovative approaches to carrying out business with customers, employees and other stakeholders."

Categorically, in a field of human resource development (HRD) whose a main goal is to improve organizational efficiency by developing individual knowledge, skills, and expertise technology has significant implications. Furthermore, it provides an exciting opportunity for HRD, it also presents difficult challenges for HRD professionals in the individual promotion and organizational learning and performance improvement (Benson, Johnson, \& Kuchinke, 2002).

For instance, almost a decade ago, Hronec (1993) projected that the role of information, in managing and evaluating initiatives related to HRD, is more significant than ever before. As a result, the successful application of HRD interventions and tools has become increasingly dependent upon the use of technology (See McWhorter \& Bennett, 2010 for thorough review). Despite wide recognition of the importance of technology to organizations, there has been little systematic research on its impact on HRD practices.

As Bennett (2009) noted, "how important new technologies have been to HRD is an open question" (p. 362-363).

Furthermore, discussions about technology's implementation in HRD, while not devoid in the field have not been adequately emphasized. Consequently, how organizations integrate technology into their work processes remains unclear.

To fill these blanks, the chapters below will explore the role of technology on the practice of HRD specifically in the next chapters below.

\section{METHODS}

HRM practices could substantially enhance a company's intellectual capital and capability to innovate. Indeed, recruiting and selection, training and development, and performance evaluation and compensation are all major determinants of organizational behavior and effectiveness (e.g.Bowen \& Ostroff,2004; Delaney \& Huselid, 1996). In line with Minbaeva (2013) and Minbaeva et al. (2009), we argue that in order to gain an innovative HRM, managers must customize traditional HRM practices into a modern one.

In order to ensure that technology has an impact on a human resource development, we need to ensure that a technology is one of a key factor of human resource. As we analyzed, There are several key factors that have had an enormous impact on the development of Human Resource. One of a module that included in a book entitled "Human Resource Management Instructor Guide" summarized that a key factors of human resource development including these points below:

- Technology: which has had, and will continue to have a significant impact in a methodology of job defining? It also challenges the workforce to keep up with 
significant developments while organizations decide which changes are worthwhile adopting.

- Globalization: as companies consider working in or expending into foreign markets, and have employees who work in different locations.

- Demographics: as the core numbers of the workforce age and move into retirement, and the available talent pool becomes smaller. What do the older workers need to survive? What are younger workers looking for in employment?

For gaining an innovative management of workforce as it is currently existing, there is a significant concern on training and development. Development (the long term process that facilitates strategic thinking) capitalizes on experience and aims to reach goals. Training is provided specifically to change behaviours or attitudes in order to meet job specific requirements.

Based on one of the article that published in smallbusiness.com, it concluded that a "New technology brings new skills requirements, so companies always need to be aware of Proficiencies and training needs when planning human resources. That is why the HR managers should be aware of new equipment or knowledge be needed so they can build the required skills, and most likely salary enhancements, into the plan".

\section{TECHNOLOGY'S CONTRIBUTION FOR INNOVATIVE HUMAN RESOURCE MANAGEMENT}

As one of a key factors of human resource development, in this chapter we would like to define it more by analyzing an impacts of technology on a development of employees. Prof. Rajesh Kumar VNS Institute of Management, Bhopal (MP) on his journal entitled Impact of Human Resource Technology has concluded that "a Globalised environment, technology based short product cycles, market growth has led organizations to tailor human resource management functions. Organizations have to review external and internal environment continuously and implement change. This is required to be growth oriented and competitive. Those organization cannot survive that do not keep human resources fully trained and management cadre developed."

For more specific impacts, a table below summarizes the positive and negative impacts on human resource management when technology is applied. R. Broderick and J. W. Boudreau (1992, p. 13) state that technology can thus free up some time to pursue more productive work. They also suggest there will be more time for innovation and quality issues.

Consequently, the firms will standardize their HR systems and use the shared HR services which will provide them with a competitive advantage (Hendrickson, 2003, p. 389).

Table 1. The Impacts of the Adopted Technology on HRM

\begin{tabular}{|l|l|}
\hline Negative Impacts on HRM & Positive Impacts on HRM \\
\hline Initial Costs & Long-term Savings \\
\hline Reduction in the Headcount & Strategic Role - New Departments \\
\hline Data Protection Compromised & Time Savings \\
\hline Outsourcing & Boosted Quality \\
\hline Responsibilities Shifted to Line Managers/Employees & Standardization \\
\hline Blurring Work/Life Balance & Enhanced Performance \\
\hline Technological Incompetence & Second Life HRM Source \\
\hline
\end{tabular}

Source: Hendrickson, 2003, pp. 391 - 392; Ruel et al., 2004, pp. 367 - 378; Sushi, 2008; Parry, Tyson, 2007, p. 242 


\section{Sukarni S}

Nowadays, technology has been developed beyond anybody's perception. Technology is being implemented to decrease distances, map anywhere on the earth, explore many issues and produce product and services that give leisure to people and so on.

Likewise, The technology has also a contributions in order to innovately develop a human resources as the provided points below :

- Jobs have been upgraded as an enhancement of intellectual's level is now required to handle most of the jobs hitter to be handled by unskilled or semi-skilled workforce.

- Highly technical jobs have produced in displacement of people unless they have kept pace with the technological development.

- For those employees, who pick up and acquaint themselves with new technology, the job will be challenging and rewarding. Working class, in general, stands to gain through increased productivity, reduced prices an increased real wages - all by product of new technology.

- Technology has attributed development and promotion of human relations. Introduction of team work, quality control teams are outcome of technology-human interface.

- Job holders have become highly knowledgeable and hard core professionals. Organizations have become "techno-structure" having an ideal combination of scientists, technocrats and management specialists.

\section{CASES OF TECHNOLOGY IMPLEMENTATION FOR HUMAN RESOURCE DEVELOPMENT}

\section{- Bangor University, United Kingdom}

Bangor University implements a lot of e-learning to assist its students for a performance's development. The method of e-learning which is applied by the university is Blackboard. This is has been brought into the mainstream of teaching and learning activities within the university. It is one of the most central systems which are not only used by the students but also the lecturers.

By using a blackboard, the lecturers are able to integrate presentations which contain both audio and video content onto the online courses. This will then go on to develop online questions and test plan which will concurrently maintain learning activity and reduce marking workloads. Furthermore, a blackboard also contains an online discussion forums in order to support the development of learners. Hereof, the blackboard is quite useful for HRD because students can be educated by other students or even lecturers by submitting questions onto the forum as an example.

Another example of e-learning which the university use is webmail. This is the emailing tool of e-learning in which students, lecturers, support staff or whoever is involved with the institute can communicate with one another or even with people outside of the university. (Bangor University, unknown)

\section{- Tesco, UK}

Tesco was looking into developing an Online Academy which was going to be a new learning portal which hopefully in the end would eventually serve a learning needs of over 400,000 staff across the global businesses. Their goal was to develop a cost-effective solution, Tesco would be partnered with Kineo to design and also deploy learning based on Moodle. 
During 2009, Tesco piloted its Academy Online portal as a proof of concept for a learning management solution and portal for their staff across this business. Tesco explored alternatives with an open source technologies, with doing so they saw a potential to make highly customised solutions with a strong focus on the user experience.

Tesco took Kineo as a partner to design and develop the portal solution based on the experience they had in term of combining user experience and web design. The reason of that is for the efficiency of their staff to understand how to apply the portal in an easy way and in a method in which they were able to extend their skills when working for Tesco, also it was to help them to manage and update the software easily. (Kineo, 2009)

\section{- Dandiah HR Consultant, Indonesia}

Dandiah HR Consultant offers a based technology program to define a development of human resources. Based on an interview that arranged by the author with the owner of Dandiah HR Consultant named Dandi, the program that offered by the consultant is able to describe a detail information of each worker such as his/her performance evaluation, strength, weakness, track record and so on.

Moreover, a program also can support a decision making. For example, by gaining an information regarding a weakness of an employee, the organization can decide to give a training in order to reduce that kind of weakness. Currently, Astra International as one of the client is applying the program and it helps the company to gain an efficiency in term of HR development and also management by implementing a features of the program.

\section{CONCLUSION}

Technology has had positive effect on internal operations for organizations, but it also changed the way human resource management work. Human Resource Information System (HRIS) allow HRM professional to better facilitate human resource plans, make decisions faster, clearly define jobs, evaluate performance, and provide cost effective benefits that employees want. Likewise, it helps to strengthen communication with both the external community and employees. Technology also dramatically changed how human resource managers orient, train, and develop employees and help them manage their careers. Teleconfencing technology allows employees to train and collaborate in groups regardless of their location.

However, despite evidence of the increasing use of Human Resource-related technology by individual firms, there has been little theory development in this area and academia has failed to give the impact of Information Technology on Human Resource in organizations from different sectors the attention it deserves. Shammy Shiri (2012).

Specifically, the HR technology that applied by most of organizations is Human Resource Information System (HRIS) which is able to automate and devolve routine administrative and compliance functions traditionally and can facilitate the outsourcing of Human Resource. With an appropriate Human Resource Information System, Human Resource staff enables employees to do their own benefits updates and address changes, thus freeing Human Resource staff for more strategic functions. 


\section{Sukarni S}

Additionally, data necessary for employee management, knowledge development, career growth and development, and equal treatment are facilitated. The managers can access the information they need to legally, ethically, and effectively support the success of their reporting employee.

Another benefit of using Information Technology in Human Resource Management as noted by many scholars is the freeing of Human Resource staff in the organization from intermediary roles, thus enabling them to concentrate on strategic planning in human resource organization and development. Caudron (2003), has also observed that Information Technology can automate other routine tasks such as payroll processing, benefits administration, and transactional activities, so that Human Resource professionals are free to focus on more strategic matters such as boosting productivity.

\section{REFERENCES}

Bernik, M., Florjancic, J., Crnigoj, D. and Bernik, I. (2007) Using Information Technology for Human Resource Management Decisions, Proceedings of the 8th WSEAS Int. Conference on Mathematics and Computers in Business and Economics, Vancouver, Canada, June 19-21, 130-133.

Bowen, D. E., \& Ostroff, C. (2004). Understanding HRM-firm performance linkages: The role of the 'strength' of the HRM system.Academy of Management Review, 29(2), 203-221

Broderick, R and Boudreau, J. W (1992). Human Resource Management, Information Technology, and the Competitive Edge. In: The Executive, 6(2) 13. ISSN 1938-9779.

Bulmash, Julie (2008). Human Resources Management and Technology. Retrived from https://catalogue.pearsoned.ca/assets/hip/.../0132270870.pdf.

Dandi, S.Psi, M.Psi, CEO of Dandiah HR Consultant (personal communication, May 1, 2017)

Dillon, Shelagh. Factors Affecting Human Resource Plans. Retrived from $\mathrm{http}: / /$ smallbusiness.chron.com/factors-affecting-human-resource-plans-61 165.html

Factors affectting Human Resource Plans Retrieved from (http://smallbusiness.chron.com/factors-affecting-human-resource-plans-61 165.html)

Hendrickson, A. (2003). Human Resource Information Systems: Backbone Technology of Contemporary Human Resources. In: Journal of Labour Research, 24(3), 391-392. ISSN 00237000.Human Resource Management. Retrived from https://play.google.com/store/apps/details?id=com.issuu.android.app

Kalmarova, Zuzana (2012). Technology Changes Human Resources Role: Divergence Versus Convergence Debate - A Case Study on Slovakia and The United Kingdom. Retrived from https://frcatel.fri.uniza.sk/hrme/files/2012/2012_1_04.pdf

Kianto, A., Sáenz, J., \& Aramburu, N. (2017). Knowledge-based human resource management practices, intellectual capital and innovation. Journal of Business Research, 81 (December 2016), 11-20. https://doi.org/10.1016/j.jbusres.2017.07.018

Lippert, S.K. and Swiercz, P.M. (2005) Human Resource Information Systems (HRIS) and technology trust, Journal of Information Science, 31/5, 340-353.

Luck, B. (2010) Innovation of Technology: Business for a New Century, www. scribd. com/doc/27947709/Innovation-of-Technology-in-Business-Slides

Minbaeva, D. (2013). Strategic HRM in building micro-foundations of organizational knowledge-based performance. Human Resource Management Review, 23(4), 378-390.

Minbaeva, D., Foss, N., \& Snell, S. (2009). Guest editors' introduction: Bringing the knowledge perspective into HRM.Human Resource Management, 48(4), 477-483. 
Parry, E and Tyson, S. (2007). Technology in HRM: The Means to Become a Strategic Business Partner? In: Storey, J.: Human Resource Management: A Critical Text. 3rd edition. London: Thomson Learning, 242.

Ruel, H. Bondarouk, T. Looise, L. (2004). E-HRM: Innovation or Irritation: An Explorative Empirical Study in Five Large Companies on Web Based HRM. In: Management Revue, 15(3), 367378.

Sharma, Rajesh, K. Impact of Information Technology on Human Resource Development. www.shaktipublication.org/userfiles/file/paper 1.pdf

Sushi, H. (2008). Out of This World. In: People Management. ISSN 1358-6297. (2015, May 23). The Role of Technology in Human Resource Development. 